\title{
Smallholders Farmers' Perceptions on the Impacts of Climate Change on Their Livelihoods in Kuje Area Councils
}

\author{
Hauwa Bako, Amade Paul Haruna, and Bako Sani Adamu
}

\section{ABSTRACT}

The study examined smallholders Farmers' Perceptionsion of the impacts of climate change on their livelihood in Kuje Area Councils of (FCT), Nigeria. Multi-stage random techniques were used to select 100 respondents. Data collected was analyzed with the use of descriptive statistics such as frequency tables, percentages. The average years of age of the respondents were 46 years. $88 \%$ of the respondents had between 1-5 hectares of land. Results on level of education show that the majority $(75 \%)$ of the respondents had a basic level of education. The mean income of respondents was $N 450,000$. Respondents perceived temperature $(\mathbf{7 6 \%})$, change in seasonal periods $(70 \%)$ and rainfall distribution $(60 \%)$ as the major effects of climate change that have led to low output of crops in the study area. Results show that measures are taken to mitigate the effects of climate change by respondents were combining farming with other sources of livelihood as $75 \%$, source information from friends and relatives on how to cop the impacts of climate change $67 \%$, adopts afforestation $48 \%$. However, $66 \%$ of the respondents in the study area had not taken any steps to cope with the effects of climate change. Major constraints faced by respondents were lack of irregular climate information $95 \%$, inadequate extension services $78 \%$ and Unpredicted rainfall $75 \%$. It was recommended that stakeholders in climatic change issues should educate the smallholders' farmers on the effects of climate change and the measures to take in mitigating the effects of climate change.

Keywords: Climate change, Livelihood, Perception, Smallholders farmers.

\author{
Submitted : December 06, 2021 \\ Published : February 08, 2022 \\ ISSN: $2684-1827$ \\ DOI: 10.24018 /ejfood.2022.4.1.432 \\ Hauwa Bako* \\ National Space Research Development \\ Agency (NASRDA), Obasanjo Space \\ Centre, Nigeria. \\ (e-mail: nhauwabako@gmail.com) \\ Amade Paul Haruna \\ Department of Agricultural Economic and \\ Extension, Faculty of Agriculture and Life \\ Science, Federal University Wukari, \\ Nigeria. \\ Bako Sani Adamu \\ Department of Agricultural Economics \\ and Extension, Nasarawa State University, \\ Nigeria.
}

*Corresponding Author

\section{INTRODUCTION}

Agriculture is the primary source of livelihood in African, and Nigeria inclusive [1]. "World Bank reports of 2007 revealed that agriculture accounts for over $70 \%$ of the active labor force, and more than $23 \%$ of the Gross Domestic Product in Nigeria (GDP)". The exploitation of natural resources especially in agriculture remains the driving force for the country's economic development and agriculture is solely climate dependent [2].

Climate according to ICPC 2004, is defined as the average weather condition of a place. There has been variation in climate change in Nigeria, because of temperature rise, changes in rainfall pattern, flooding, rise in sea level, drought, desertification, loss of biodiversity and land degradation are also not left out. "The extreme weather occurrence has present severe threats and erode essential needs, capabilities and rights more especially for the poor and marginalized thereby redesigning their livelihoods" [3].

Smallholder farming systems remain the only source where $60 \%$ of African foods come from as they provide livelihoods for hundreds of millions of the world's poorest households [4]. According to Girei et al. [5], Nigeria agriculture is predominantly small-scale farmers with landholding of 10 hectares, who engaged in the production of the bulk of food that is required by these groups who makes up about $80 \%$ of the farming population and are responsible for $80-90 \%$ of food production in Nigeria.

Climate variation in Nigeria has affected economic growth especially in Areas that are dependent on climatic conditions such as agriculture, fishery, and forestry and those not directly dependent on climatic conditions, but the effects of climate change have an adverse effect on its production indirectly which includes weaving, construction, businesses, non-agricultural labor.

ADCOM report of 2021 reveals that Nigeria is placed among the ten most vulnerable countries in the World Climate Vulnerability Index, as it ranked 18 of 135 countries by the German Watch's Climate. While Notre Dame's Global Adaptation Initiative Index, Ranked the country Risk Index as 160 of 181 countries. All these factors melted on livelihoods of small-scale farmers, and this calls for the urgent attention of stakeholders to help fight the menace of climate change in Nigeria [7]. Adapting to Climate change requires preparation for the current and future impacts that may happen as a result of change in weather conditions, it also means changing our activities and decisions so that we reduce the negative impacts of climate change and become more resilient. "The need for adaptation strategies that will help the poor small-scale farmers who lack the basic knowledge on the adverse effects of climate change should 
be a motivating factor so has to stop food insecurity in the country" [3]. Climate change has been labeled as a new security threat to Africa. According to Azees and Aloko [8], "predicts farmers headers conflicts as a result of climate change which has affected the pastoral farmers access to shrubs thereby encroaching on farm settlements. Climate Change has hindrance to production and profitability. Skillful seasonal climate forecast information could become important to farmers' production decisions because the information would help farmers in their decision-making regarding farm activities while farm management practices can be formed better with the aid of seasonal climate forecast [9]. "The impacts of global climate change on agricultural production are a serious source of worry to farmers in subSaharan Africa. This is because their economies mainly depend on agriculture which is now affected by climate change catastrophes" [10]. The new threat to Africa, is known as Climate variation as it harmfully affects all food elements and livelihood sources security.

\section{THE STUDY'S OBJECTIVES}

This study intends to analyze the Perception on Effects of Climate change on the Livelihood of Smallholders Farmers in Kuje Area Councils.

The specifics Objectives were:

i. Describes socio-economic characteristics of smallholder's farmers in the study area.

ii. Assess perception of the impacts of climate change in the area.

iii. Identify the measure taken to mitigate the effects of climate change in the area.

iv. Identify the constraints faced by farmers in coping with the impacts of climate change in the study area.

\section{MATERIAL AND METHODS}

The study was conducted in Kuje Area councils of the Federal capital territory, Abuja, Nigeria. The Councils lies within latitude: $8^{\circ} 52^{\prime} 46.27^{\prime \prime}$ longitude: $7^{\circ} 13^{\prime} 39.22^{\prime \prime} \mathrm{E}$ with an elevation of $373.00 \mathrm{~m} / 1223.75$ feet. It has an area of $992 \mathrm{~km}^{2}$ and a Population of 97,367 NPC 2006. It has 10 wards and they are Chibiri, Gaube, GudunKarya, Gwargwada, Kuje town, Kujekwa, Kwaku, Yenche and Kabi. It has an annual rainfall of $727 \mathrm{~mm}$. The major occupations of the people in the area are farming and fishing.

\section{A. Sampling Technique}

A multistage sampling technique involving Purposive and random sampling techniques was used to select respondents for the study. The first stage was a purposively selection of 5 wards (Gudun, Gwargwada, Chibiri, Kwaku and Kabi) that are major in farming from the 10 wards that make up the area councils. The second stage involves random sampling of 20 farmers from each of the selected 5 wards to make up a total of 100 respondents that served as the sample size for the study.

\section{B. Data Collection}

Primary data were collected with the aid of a structured questionnaire that was administered to the respondents for this study. Data was collected on socio-economic characteristics of farmers, the perception of the effects of climate change, measures taken to mitigate the effects of climate change and constraints faced by farmers in coping with climate change in the study area.

\section{Methods of Data Analysis}

Simple descriptive statistics such as frequency distribution, mean and percentage were used to achieve objectives (i, ii, iii, and iv).

\section{RESUlT AND Discussion}

\section{A. Socio-Economic Characteristics of Respondents in the Study Area}

The results in Table I on the socio-economic characteristics of the respondents in the study areas shows that in gender, the majority $(72 \%)$ were males while $28 \%$ were female. This indicates that men are more dominant in farming in the area compared to women. This could be because of the female involvement in domestic chores in the family. The results on age revealed that $55 \%$ of the respondents fall within the age brackets of 41-50 years, while $23 \%$ fall within the age bracket of 31-40 years. The mean age of the respondents in the study area was 46 years. This implies that respondents in the study area were middle-aged farmers and still had some energy to cope with the effects of climate change and carry out activities on the farm. Marital status shows that most of the respondents, about $91 \%$, were married. The results in Table I also reveal that $51 \%$ of the respondents had education, $19 \%$ had secondary education, and $5 \%$ had tertiary education, while $25 \%$ had no formal education. Education makes farmers enlightened enough to be able to adopt available innovations when introduced to them. Variables of years of farming show that $66 \%$ of the respondents had $1-5$ years of experience, while $22 \%$ had 6-10 years of experience. This indicates that respondents in the study area have a considerable number of years of farming experience. The results on farm size show that $88 \%$ of the respondents had 1 5 hectares of farmland, while $22 \%$ had 6-10 hectares of farmland. The mean farm size was 2.4 hectares. The results on household size reveal that $44 \%$ had a household size of 7 9 persons, while $38 \%$ had a household size of 4-6 persons. The mean household size was 7. This implies that respondents in the study area have a low number of people that can help in farming activities. The results further shows that $65 \%$ of the respondents earn an annual income of between $\mathrm{N} 200,000$ and $\mathrm{N} 400,000$, while $30 \%$ earn within the range of N401,000-N600,000, and only 5\% earn above $\mathrm{N} 1,000,000$. The mean annual income was N345,000. The Mean annual household income was $\$ 40,000.00$. "These categorized the farmers in the study area as a resource poor farmers because they farm on land between 0.1-5.99 hectares" [11]. This implies that they were mainly subsistence farmers who had very limited capacity to practice commercial farming. Consequently, they are also expected to have a very weak capacity to adapt to the fast-changing climate, which has adverse effects on agriculture and food production if some abatement strategies are not strictly adopted. The major occupation in the study area was full-time farming, which accounted for about $62 \%$ of the respondents. Another $26 \%$ of 
the respondents combined farming and trading, 5\% combined farming and livestock keeping, and 7\% combined farming and public services. Results on sources of credits revealed that $61 \%$ of the respondents got no credits and $30 \%$ got credits of between $\mathrm{N} 20,000$ and $\mathrm{N} 40,000$. The results on extension contacts show that $25 \%$ had no contact with the extension agents while $60 \%$ had 1-2 contacts with the extension agents. This suggests that extension visits in the study area were poor, and this will lead to farmers lacking basic information in terms of adaptive and mitigation strategies that would have helped them overcome the dangers of climate change.

TABLE I: SOCIOECONOMIC-CHARACTERISTICS OF SMALLHOLDERS FARMERS IN THE STUDY AREA

\begin{tabular}{|c|c|c|c|}
\hline Variable & Frequency & $\begin{array}{c}\text { Percentage } \\
(\%)\end{array}$ & Mean \\
\hline \multicolumn{4}{|l|}{ Age(years) } \\
\hline $20-30$ & 5 & 5.0 & \\
\hline $31-40$ & 23 & 23.0 & \\
\hline $41-50$ & 55 & 55.0 & \\
\hline 60 Above & 17 & 17.0 & \\
\hline \multicolumn{4}{|l|}{ Gender } \\
\hline Male & 72 & 72 & \\
\hline Female & 28 & 28 & \\
\hline \multicolumn{4}{|l|}{ Marital status } \\
\hline Single & 4 & 4 & \\
\hline Married & 91 & 91 & \\
\hline Divorced & 5 & 5 & \\
\hline \multicolumn{4}{|c|}{ Household size (number of persons) } \\
\hline $1-3$ & 12 & 12 & \\
\hline $4-6$ & 38 & 38 & \\
\hline $7-9$ & 44 & 44 & \\
\hline 10 above & 6 & 6 & \\
\hline \multicolumn{4}{|l|}{ Level of education } \\
\hline No formal & 25 & 25 & \\
\hline Primary education & 51 & 51 & \\
\hline Secondary education & 19 & 19 & \\
\hline Tertiary & 5 & 5 & \\
\hline \multicolumn{4}{|l|}{ Farm size (in hectares) } \\
\hline $1-5$ & 88 & 88.0 & \multirow{2}{*}{100} \\
\hline $6-10$ & 22 & 22.0 & \\
\hline \multicolumn{4}{|c|}{ Farming experience (in years) } \\
\hline $1-5$ & 66 & 66.0 & \\
\hline $6-10$ & 22 & 22.0 & \\
\hline Above 10 & 12 & 12.0 & \\
\hline \multicolumn{4}{|c|}{$\begin{array}{l}\text { Extension contacts (number of } \\
\text { times) }\end{array}$} \\
\hline No contacts & 25 & 25.0 & \\
\hline $1-2$ & 60 & 60.0 & \\
\hline $3-4$ & 15 & 15.0 & \\
\hline \multicolumn{4}{|c|}{ Access to credit (amount in naira) } \\
\hline No access & 71 & 71.0 & \\
\hline N 20,000- N40,000 & 30 & 30.0 & \\
\hline $\mathrm{N} 41,000-60,00$ & 5 & 5.0 & \\
\hline Above100,000 & 4 & 4.0 & \\
\hline \multicolumn{4}{|l|}{ Sources of credits } \\
\hline Family/friends & 71 & 71.0 & \\
\hline Co-operatives & 12 & 12.0 & \\
\hline Producers & 15 & 15.0 & \\
\hline Banks & 2 & 2.0 & \\
\hline \multicolumn{4}{|c|}{ Annual income (amount in naira) } \\
\hline N200,000- N400,000 & 65 & 65 & \\
\hline N401,000- N600,000 & 30 & 30 & \\
\hline Above N 1,000,000 & 5 & 5 & \\
\hline
\end{tabular}

\section{B. Perception on the Effects of Climate Change}

1) Farmers perceptions on climate change's effects in the study area

In terms of respondents' perspectives of climate change in the research area, the majority $(76 \%)$ of respondents indicated that temperature has been on the increase in recent years, Rains that used to fall regularly during the planting season, according to $70 \%$ of farmers, were becoming more erratic, and when they did fall, they were often in heavy bursts that caused floods and little infiltration. About $(60 \%)$ of the respondents indicated that rainfall has been reducing in the last few years leading to low output. About (70\%) of the respondents opined that rainfall distribution and (65\%) change in seasonal periods leads to flooding. However, poor germination of crops was attributed to all the climatic factors in the study area as the major causes. Wilting of the crops was attributed to sunshine and increased temperature which is $(65 \%)$ and $(55 \%)$. The climatic factors that affected postharvest loss in the area were changes in seasonal variation and Rainfall distributions (67\%) and (58\%) respectively. Draught was affected by sunshine $(87 \%)$. Pest and diseases were perceived to be because of increased temperature and rainfall distributions. Rainfall and temperature are the two climatic variables that influence farming the most. The amount of rainfall is important so has the pattern. Climate changeextremes has led to poor harvest and an increase in food prices. This agrees with the findings by Adégnandjou and Dominique [12] who reported that $70-80 \%$ of the respondents in South Benin Republic observed changes as a result of rainfall distributions, increase in temperature, the intensity of the sun, violent winds and other extreme events such as floods. The result is also inconsonant with Falaki et al. [13] in their study of climate change in North Central Nigeria revealed that increased climate variability was observed on rainfall distribution, and these have an adverse effect on agricultural productivity.

\begin{tabular}{ccccc}
\multicolumn{5}{c}{ TABLE II: PERCEPTION ON IMPACTS OF CLIMATE CHANGE IN THE AREA } \\
\hline $\begin{array}{c}\text { Effects of } \\
\text { climate } \\
\text { change }\end{array}$ & $\begin{array}{c}\text { Climatic } \\
\text { increased } \\
\text { change in } \\
\text { temperature }\end{array}$ & $\begin{array}{c}\text { Factors } \\
\text { Sunshine } \\
\text { intensity }\end{array}$ & $\begin{array}{c}\text { Rainfall } \\
\text { distribution }\end{array}$ & $\begin{array}{c}\text { Change in } \\
\text { seasonal } \\
\text { distribution }\end{array}$ \\
\hline $\begin{array}{c}\text { low farm } \\
\text { output }\end{array}$ & 76 & 45 & 60 & 70 \\
$\begin{array}{c}\text { Flooding } \\
\text { Poor }\end{array}$ & 25 & 34 & 70 & 65 \\
$\begin{array}{c}\text { germination } \\
\text { Wilting of } \\
\text { crops }\end{array}$ & 67 & 56 & 78 & 56 \\
$\begin{array}{c}\text { Post-harvest } \\
\text { lost }\end{array}$ & 45 & 65 & 45 & 38 \\
$\begin{array}{c}\text { Drought } \\
\text { Pest and } \\
\text { diseases }\end{array}$ & 50 & 87 & 56 & 67 \\
\hline
\end{tabular}

Source: Field Survey, 2021.

\section{2) Measures Taken to Mitigate the Effects of Climate Change in the Study Area}

From the results, it can be deduced that $75 \%$ of the respondents had to combine farming with other sources of livelihood and by practicing diversified traditional farming systems These include Intercropping,which is a farming method whereby the main crop is planted with one or two crops planted in-between as subsidiaries or at low density. Farmers gave instances where yam (tuber) may be planted as the main crop while maize (cereal) and melon (legume) are planted as subsidiaries at different times in the growing season. According to farmers, this method increases total crop harvest and maximizes the microclimate. 
Multiple cropping: This is a method whereby many crops are planted at the same time on a piece of land. This is very common in the study area. Farmers may decide to plant two to four crops on the same plot, depending on an individual. Many combinations of crops were given by the farmers, such as yam, cassava, pepper, okro, etc. According to the farmers, the crops are not always planted at the same time but at different times during the growing season.

Diversification of crops: In the study area, it was revealed that smallholder farmers do not depend on a single food crop (monoculture) but cultivate a diversity of crops on one or more plots of land.

About $67 \%$ got information from friends and relatives on how to mitigate the effects, while $66 \%$ of the respondents in the study area had not taken any steps to cope with the effects of climate change.

TABLE III: MEASURES TAKEN TO Mitigate THE EFFECTS OF ClimATE CHANGE

\begin{tabular}{ccc}
\hline Measures taken & Frequency & Percentage (\%) \\
\hline Diversifications of livelihood & 75 & 75.0 \\
Source information from friends and relatives & 67 & 67.0 \\
Encouragements of afforestation & 48 & 48.0 \\
Increase in technical know out & 40 & 40.0 \\
Sources information from extension agents & 45 & 45.0 \\
Appeal to the government to help & 50 & 50.0 \\
No steps taken & 66 & 66.0 \\
\hline
\end{tabular}

Source: Field survey, 2021.

Multiple responses $* * *$.

\section{3) Constraints to Climate Change in the Study Area}

Results on constraint to climate change in Table IV reveal that $95 \%$ of most of the respondents opined that lack of information is the most outstanding constraint faced on effects of climate change and $78 \%$ of the respondents observed that there were inadequate extension services. This implies that smallholder farmers in the study area viewed insufficient information about climate change and lack of knowledge about appropriate coping strategies serious lacks. Agricultural extension services are important mechanisms for climate change information dissemination, education, and capacity building; they are crucial determinants of adaptive capacity. In essence, extension services are fundamental to aiding smallholder farmers to cope and adapt to climate change. On the other hand, human interference to nature was the least faced in the study area.

TABLE IV: CONSTRAints To Climate CHANGE IN THE STUdy AREA

\begin{tabular}{ccc}
\hline Constraint & Frequency & Percentage (\%) \\
\hline Lack of regular climate & & \\
information & 95 & 95.0 \\
Inadequate extension services & 78 & 78.0 \\
Human interference to nature & 30 & 30.0 \\
Unpredicted rainfall & 75 & 75.0 \\
Problems associated with Flooding & 52 & 52.0 \\
$\quad$ and drought & & \\
Inadequate governments & 46 & 46.0 \\
contribution & & \\
\hline
\end{tabular}

Source: Field survey, 2021. multiple responses.

\section{CONCLUSIONS AND RECOMMENDATIONS}

The study examined smallholders' farmers' perception of climate change in the area. The study area practiced rain-fed farming, invariably climate change has adverse effects on the livelihood of the people, as respondents' perception of trends in climatic factors shows rainfall distribution and seasonal variations as not being consistent. Based on the findings of this study, it can be concluded that Respondents were vulnerable to climate risk and have little or no management strategies to mitigate the effects of climate change. There is a need to educate and train respondents to cope with the changing climate by organizing programmes such as smartagro-climate through the extension workers. All stakeholders should work with research institute to give climatic information that can be disseminated to the rural areas that have no access to climatic data.

\section{REFERENCES}

[1] Sowunmi F.A. and Akintola J. O. Effect of Climatic Variability on Maize Production in Nigeria. Research Journal of Environmental and Earth Sciences, 2010; 2(1): 2041-0492.

[2] Dinar A. Climate Change and Agriculture in Africa. Hassan R., Mendelsohn R., Benhin J. Impact Assessment and AdaptationStrategies., 2006, ( $1^{\text {st }}$ ed.; pp. 221). Routledge. https://doi.org/10.4324/9781849770767.

[3] Philip A.U, Millar K. K., Ikpe E.Q., Joyce A. and Bernard A.A. The Effects of Climate Change on Livelihoods of Smallholder Farmersin the Upper East Region, International Journal of Sciences: Basic and Applied Research, 2016, 01;28(3): 1-20.

[4] Girei A.A, Saingbe N.D., Ohen S.B and Umar K.O, et al. Economics of Small-Scale Maize Production in Toto Local Government Area, Nasarawa State, Nigeria. Agrosearch, 2018, 14;18(1): 90-104.

[5] Fatoki O.A., Adesope A.A., Awe Femi O.T., and Arowolo O.V. Assessment of smallholder farmers vulnerability to climate change in Ogun state, Nigeria. Journal of Agricultural and Socio-Economic Sciences, 2020, 20; 6(102): 136.

[6] Azeez I.O., and Aluko O.J. Analysis of Factors Instigating Land Use Conflicts in Selected Forest of Ondo State, Nigeria. Journal of Environmental Protection Reserves, 2019;2(32):614-624.

[7] Zack G., Andrew Z., S. L, Corrie H., Drew G., Kurt W., Natasha K., Justin S., Kelly C., Tom E. Farmer forecasts: Impacts of seasonal rainfall expectations on agricultural decision-making in Sub-Saharan Africa. https://doi.org/10.1016/j.crm2020 (2).100247.

[8] Arora, N. Impact of climate change on agriculture production and its sustainable solutions. Journal of Environmental Sustainability, 2019;2(1):95-96.

[9] Rapsomanikis G. The economic lives of smallholder farmers. $2015,15^{\text {th }}$ edition. DOI:10.13140/RG.2.1.3223.9440

[10] Nwaiwu I.U.O., Ohajianya D.O., Orebiyi J.S., Ibekwe U.C., and Eze C.C. Effects of climate change on labour time allocation to food crop production- a case study of Southeast Nigeria. Global Journal of Current Research. 2013;1(4):108-115.

[11] Adégnandjou M.R. \& Dominique B. Farmers' adaptation strategies to climate change and their implications in the Zou Department of South Benin. Journal of Environments, 2018;5(1):15. https://doi.org/10.3390/environments5010015.

[12] Falaki A.A., Akangbe J.A., Iyilade A.O. and Olowosegun T. Small Scale Farmers' Perception and Adaptation to Climate Change in Nasarawa State of Nigeria. Agrosearch, 2011;11(12): 49-62.

[13] Arimi K. Determinants of climate change adaptation among cocoa farmers in Southwest Nigeria. Journal of Agriculture and Rural Development in the Tropics and Subtropics, 2014;115(2):91-99.

[14] Avery S. C, Peter N., Juliana D.B., Laura K., Leah S., Vincent R., Jessica R. M, and Sarah N. et al. Smallholder Agriculture and Climate Change, Jounal of Environment and Resources, 2017 Oct;(42):347375 .

[15] Ayansina A., Mareen R. and John F.M. Comparing smallholder farmers' perception of climate change with meteorological data: A case study from southwestern Nigeria. Jounal of Werther and climate change, 2017;16(4):24-33.

[16] Ayinde O.E., Ajewole O.O., Adeyemi U.T., and Salami M.F. Vunerability Analysis of Maize Farmers to Climate Risk in Kwara State, Nigeria. Agrosearch, 2018;18(1):25-39.

[17] National Population Census. Population reports 2006.

Olayemi S. S. Constraints Facing Smallholders Farmers' Access to Market: TheCase Study of Kaduna State, Nigeria. African journal of Agricultural Studies, 2021;1(1):382-391. 